which are within the reach of almost every one, and while confining himself pretty strictly to the description of strictly microscopic objects, contrives at the same time to furnish a tolerable general sketch of the animal kingdom.

Of the vertebrates, of course, Mr. Gosse cannot speak as microscopic objects, but he describes the structure of hairs, feathers, and scales, and the characters presented by the blood of these animals. Had he gone a little further and noticed the structure and mode of formation of bones and teeth, and of some of the more important soft parts, he might have made this section of his work far more instructive. In the treatment of the invertebrate animals, Mr. Gosse arranges his subject in accordance with the generally received classification, devoting a chapter or more to each of the great groups or classes (which he notices separately), and describing in a clear and pleasant style all those parts in the investigation of which the use of the microscope is necessary. Not unnaturally the Rotifera, the SeaAnemones, and some other groups, upon which Mr. Gosse has worked with results well known to all zoologists, come in for a favourite's share of his attention: but on the whole he has behaved with a commendable impartiality; and the student who works through the course of study here laid down by Mr. Gosse, will rise from his labour with no contemptible amount of zoological knowledge. We may add that the book is adorned with a considerable number of good wood-engravings, and, although published by the Society for promoting Christian Knowledge for the express purpose of indicating the wonders of the Divine handiwork in the animal world, is not disfigured by any undue obtrusion of the natural-theological element, such as we are but too much accustomed to in many books with a similar purpose.

\title{
MISCELLANEOUS.
}

Note on Ablepharus pusillus. By W. T. Btanford.

In the description of the above-named species in the 'Annals' for July last, p. 33 of the present volume, a serious error occurs, the number of transverse rows of ventral scales between the axils being stated to be 26 instead of 36 . The latter number is correct; and as the only important difference between $A$. pusillus and A. Brandti, Strauch, consists in the number of scales between the axils, which are fifty in the last named form, whilst Blepharosteres agilis of Stoliczka (Proc. As. Soc. Bengal, 1872, p. 126) has forty to forty-five, and appears from the description to agree in every other character of importance with the other two species, there is every probability that these three races must be considered varieties of one species, which will bear Strauch's name A. Brandti. The type of the latter is from Turkestan ; Dr. Stoliczka's species is from the Punjab; and A. pusillus was procured by me close to Basrah, commonly called Bussorah, the port of Mesopotamia on the estuary of the united Tigris and Euphrates; so this scinque has a wide range in Asia. Ann.\&Mag. N. Hist. Ser.4. Vol.xiv. 


\section{The Winged Fruits of the Carboniferous Genus Cardiocarpus.}

The genus Cardiocarpus was probably related to the modern Conifers of the Welwitschia type, as shown by the similarity of the fruit and also by the close relation of the leaves, if those called Cordaites belong, as both Geinitz and Newberry have independently remarked, to Cardiocarpus. The Welwitschia is an embryonic form of Conifer, it producing no leaves except the cotyledonous; but, while probably unlike Cordaites in its embryonic features, it shows what leaves and fruit are consistent with the type of Conifers.Dana's Manual of Geology, New Edition, pp. 328, 330.

\section{Remarks on the Fishes of the Algerian Sahara. By M. P. Gervais.}

In the communications which have recently been made to the Academy on the subject of the possibility of establishing a sea in the Algerian Sahara, there have been urged, successively for or against that project, facts derived from geology, botany, and even zoology. In fact M. Cosson, calling in the aid of this last branch of natural history, has cited the Coptodon Zillii, described by me, as proving the continuity of the sheet of water under this region*.

This Coptodon, which M. Valenciennes has proposed to unite with Glyphisodon, a genus of marine fishes, although it differs therefrom in several characters, and especially in the non-ctenoid character of its scales, has received several other denominations. It is the Perca Guyonii of Heckel; and Dr. Günther has made it the type of a new genus under the name of Hatigenes Tristrami ; but it had been previously indicated under the name of Bolti from examples collected in other parts of Africa, principally in the Nile; and it is also the Tilapia of Andrew Smith, who had the opportunity of observing it in South Africa. It is known also in the Senegal and Mozambique, and everywhere lives in fresh water. We cannot say, therefore, like Dr. Tristram, that in Algeria it may be regarded as a last living vestige of the fauna which peopled the Saharian sea during the Tertiary epoch " before the elevation of the ground in Northern Africa poured into the Mediterranean the waters of that vanished ocean."

In my memoir on the fishes of Algeria + I brought forward the objection which the essentially fluviatile character of the Bolti enables us to oppose to this opinion, and indicated that this was also the case with the Cyprinodon, which is likewise ejected by the artesian waters of the Sahara under the same conditions; and I added that $I$ did not think we ought any longer to accept the expression that has been sometimes employed with regard to this genus of fishes (namely, that they are derived from a sea stretching beneath the region in question), seeing that, wherever we know the Cyprinodons, they are, like the Bolti, exclusively proper to fluviatile or lacustrine waters, and, like it, are strangers to the sea. This is what we ascertain, whether we observe these fishes in Algeria or capture them in Portugal, Spain, Syria, Egypt, and even in America. Moreover the fossil Cyprinodonts which Agassiz names Lebias are like-

* See 'Comptes Rendus,' tome lxxix. p. 934.

† Zool. et Pal. gén. p. 200. 


\section{$2 \mathrm{BHL}$ Biodiversity Heritage Library}

Blanford, W. T. 1874. "Note on Ablepharus pusillus." The Annals and magazine of natural history; zoology, botany, and geology 14, 461-462.

https://doi.org/10.1080/00222937408681011.

View This Item Online: https://www.biodiversitylibrary.org/item/63340

DOI: https://doi.org/10.1080/00222937408681011

Permalink: https://www.biodiversitylibrary.org/partpdf/58782

\section{Holding Institution}

University of Toronto - Gerstein Science Information Centre

\section{Sponsored by}

University of Toronto

\section{Copyright \& Reuse}

Copyright Status: NOT_IN_COPYRIGHT

This document was created from content at the Biodiversity Heritage Library, the world's largest open access digital library for biodiversity literature and archives. Visit BHL at https://www.biodiversitylibrary.org. 